\title{
EDUKASI PENGELOLAAN SAMPAH DAN PENDAMPINGAN PENGGUNAAN MESIN PEMBAKAR SAMPAH DI DESA SEMANGAT DALAM
}

\author{
Rendi, Jainal Arifin, Firda Herlina, Sobar Ihsan, Budi Hartadi \\ Muhammad Suprapto, Muhammad Irfansyah \\ Program Studi Teknik Mesin, Fakultas Teknik, Universitas Islam Kalimantan \\ Email: rendi.teknikmesin@gmail.com
}

\begin{abstract}
ABSTRAK
Sampah menjadi permasalahan utama dalam kehidupan kita sekarang ini, jika sampah tidak dikelola dengan baik makan akan berakibat patal bagi lingkungan. Pengandian kepada masyarakat ini bertujuan unrtuk mengedukasi masyarakat di Desa Semangat Dalam untuk mengelola sampah dengan sistem membakar sampah tanpa asap. Metode yang digunakan adalah 1). membuat alat pembakar sampah tanpa asap 2). Sosialisasi metode ini dilakukan untuk memperkenalkan kepada masyarakat mengenai alat pembakar sampah tanpa asap. Hasil pengabdian kepada masyarakat alat pembakar sampah tanpa asap terdiri dari komponen utama tungku pembakaran sampah, saluran asap menuju filter, dan nozel saprai. Dalam sosialisainya Jumlah kehadiran peserta yang hadir sesuai dengan yang diharapkan yaitu berjumlah 15 peserta, peserta antusias mengikuti kegiatan hingga akhir dan aktif bertanya saat sesi diskusi dan tanya jawab dan Ada beberapa peserta ingin membuat alat pembakar sampah di rumahnya masingmasing.
\end{abstract}

Kata Kunci : Sampah, Polusi Udara, Pembakaran

\section{PENDAHULUAN}

Sampah selalu menjadi permasalahan utama yang dihadapi oleh sebuah wilayah. Pertambahan penduduk, peningkatan ekonomi dan perubahan gaya hidup menjadi penyebab utama banyaknya sampah. Saat ini, sampah terutama sampah rumah tangga semakin hari semakin meningkat ini di karenakan rendahnya kesadaran masyarakat dalam mengelola sampah (W. Wardi, 2011)

Dalam Undang-undang Nomor 18 tahun 2008 disebutkan bahwa sampah adalah sisa kegiatan sehari-hari manusia dan/atau proses alam yang berbentuk padat. Pengelolaan sampah yang kurang baik dapat menimbulkan kerugian diantaranya menimbulkan bau busuk, mengganggu keindahan, menyebabkan banjir, dan ancaman meningkatnya berbagai macam penyakit. Ada beberapa cara dalam pengelolaan sampah diantaranya adalah dengan cara pembakaran, cara ini lah yang paling banyak di lakukan oleh masyarakat terutama di wilayah pedesaan atau di 
komplek-komplek perumahan (Riswan , etc, 2011)

Pengelolaan sampah dengan proses pembakaran memang sangat efektif dan efesien dan bisa dilakukan oleh semua orang tetapi muncul permasalahan yaitu asap dari hasil pembakaran dapat mengakibatkan pencmaran udara. Menurut lembaga EFA asap membakar sampah dapat melepas zat beracun ke udara seperti zat Nitrogen oksida, Karbon monoksida dan Partikel polusi. Selain menghasilkan zat-zat beracun, pembakaran sampah juga akan berakibat pada kesehatan seperti iritasi, gagnguan pernapasan, mengganggu sistem peruduksi bahkan bisa menyebabkan kangker dan kematian (Arinih, Cici. 2019)

Ada beberapa cara yang dapat dilakukan untuk membakar sampah tampa menghaslkan asap, salah satunya adalah dengan teknik membasahi asap dengan percikan air atau disbut dengan metode Spray. Metode sapray ini adalah meode yang paling sederhana dan tidak membutuhkan peralatan khusus. Peralatan yang dibutuhkan untuk pembakar sampah dengan metode sprai adalah tempat penampungan sampah, penampungan air, blower, nozele saprai dan pompa air (Eko Naryono dan
Soemarno, 2013.) \& Permana ,Agus Ganda Dan Muhammad Iqbal. 2020

Berdasarkan hasil ovservasi yang dilakukan di desa Semangat Dalam jalan khususnya di sungai 2 Kabupaten Barito Kuala tingkat kesejahteraan dan ekonomi warga cukup baik Namun, peran masyarakat dalam pengelolaan sampah masih belum optimal. Hal ini terlihat dari masih banyak ditemukan sampah yang berserakan di beberapa ruas jalan. Disamping itu juga, sebagian besar warga selalu membakar sampah di depan atau di belakang halaman rumah. Hal ini disebabkan oleh karena kurangnya pengetahuan warga terhadap pengelolaan sampah baik. Selain itu, belum adanya tempat sampah serta belum maksimalnya dukungan dari pemerintah desa dalam pengelolaan sampah menjadi faktor lain alasan warga membakar sampah. Melihat fenomena tersebut, maka perlu dilakukan upaya untuk meningkatkan peran aktif masyarakat, baik melalui pemberian edukasi berupa penyuluhan, pelatihan maupun dalam praktek kegiatan pengolahan sampah secara langsung. 


\section{METODE}

Model pendekatan yang diterapkan pada kegiatan pengabdian ini adalah dengan melibatkan mitra yaitu warga masyarakat Desa Semangat Dalam secara langsung baik sebagai subyek maupun obyek pelaksanaan kegiatan mulai dari tahap perencanaan, pelaksanaan hingga evaluasi program kegiatan melalui pemanfaatan teknologi tepat guna yaitu alat pembakaran sampah tanpa asap yang dilaksanakan melalui himbauan dan dukungan tanpa unsur paksaan sehingga mitra dapat berperan secara aktif yang dikemas dalam bentuk kegiatan berupa sosialisasi, pelatihan, pendampingan. Adapun metode pelaksanaan kegiatan pengabdian ini adalah:

\section{Membuat alat pembakar sampah}

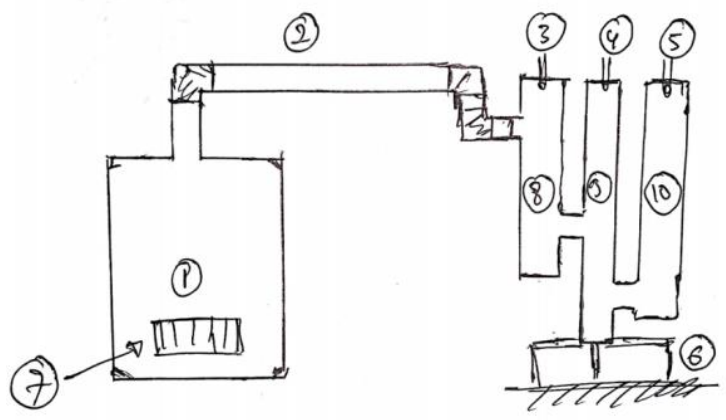

Gambar 1 desain alat pembakar sampah

Keterangan Gambar :

1. Tungku pembakaran sampah

2. Saluran asap menuju filter

3. Nozel saprai filter pertama
4. Nozel saprai filter kedua

5. Nozel saprai filter ketiga

6. Bak penampungan air

7. Pintu masuk sampah

8. Fileter pertama

9. Filter kedua

10. Filter ketiga

\section{Sosialisasi}

Dalam memberikan sosialisasi mengenai pengelolaan sampah kami menghadirkan narasumber yang berpengalaman. Adapun materi yang akan disampaikan yaitu :

1. Sampah organik dan non organik

2. Dampak negatif pembakaran sampah

3. Pengelolaan sampah dengan metode pembakaran

\section{HASIL DAN PEMBAHASAN}

\section{Pembuatan Alat}

Alat pembakar sampah adalah salah satu alat yang digunakan untuk membakar sampah minim pulusi udara. Ini adalah salah satu cara pengolahan sampah yang melibatkan pembakaran sampah secara tertutup. Prinsif kerjanya, sampah dimasukan dari atas dan dibakar dalam tungku pembakaran. Dalam pembuatan alat pembakar sampah alat-alat yang kami butuhkan 
yaitu pompa air, nozle sapry, tungku pembakaran sampah, dan penampungan air Rangkayan di susun seperti pada gambar berikut :

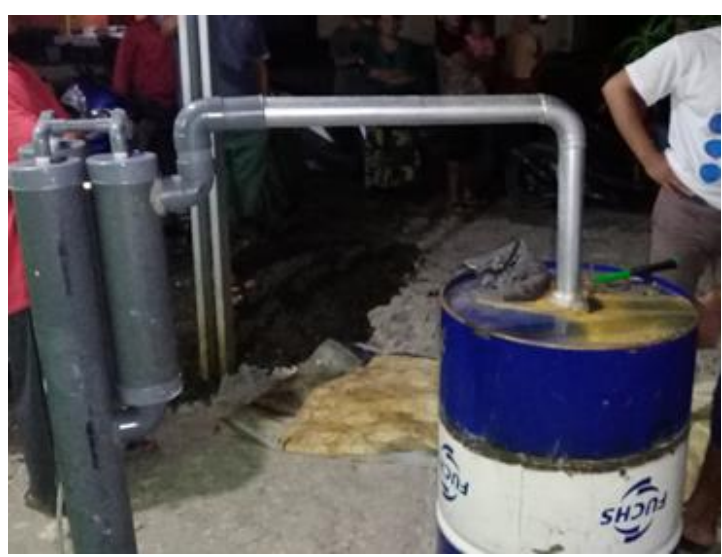

Gambar 2. Rangkaian alat pembakar sampah

\section{Sosialisasi Pengolahan Sampah}

Kegiatan ini bertujuan untuk memberikan edukasi dan peningkatan kesadaran peserta tentang cara penanganan sampah yang masih salah dimasyarakat dan dampak dari pengolahan sampah yang tidak ramah lingkukan seperti di bakar yang akan menghasilkan polusi udara dan menghasilkan zat-zat beracun yang dapat mengganggu kesehatan. Pada kegiatan ini juga diperkenalkan teknologi pengolahan sampah yang dapat mengatasi permasalahan sampah di lingkukanga masyarakat. Indikasi keberhasilan kegiatan ini diukur dengan tingkat kehadiran peserta dan antusias peserta dalam mengikuti kegiatan dari awal hingga akhir. Hasil kegiatan menunjukkan bahwa:

1. Jumlah kehadiran peserta sesuai dengan yang diharapkan yaitu berjumlah 15 peserta tingkat kehadiran peserta hampir $80 \%$. Dari semua undangan

2. Peserta juga sangat antusias mengikuti kegiatan hingga akhir dan aktif bertanya saat sesi diskusi dan tanya jawab.

3. Ada beberapa peserta juga yang ingin membuat alat pembakar sampah di rumahnya masingmasing.
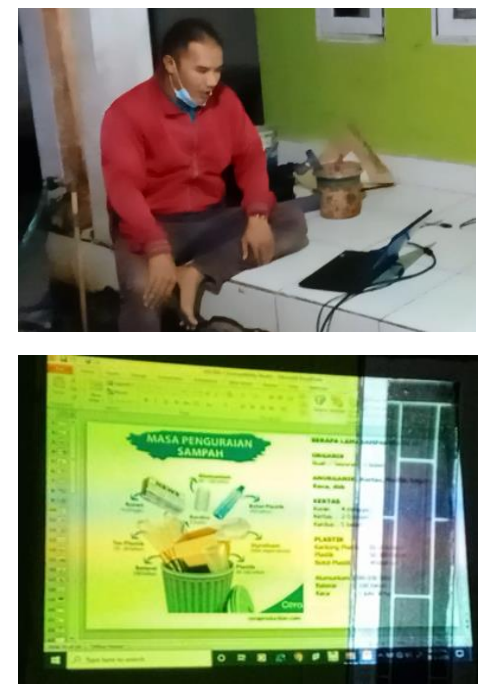

Gambar 3 penyampaian materi

sosialisasi oleh anggota tim

\section{Memperkenalkan Alat Pembakar}

\section{Sampah}

Kegiatan ini betujuan untuk memberikan pemahaman kepada peserta tentang teknologi pembakar sampah yang bisa dibuat di rumahnya 
masing-masing dengan menggunakan peralatan perlatan sederhana
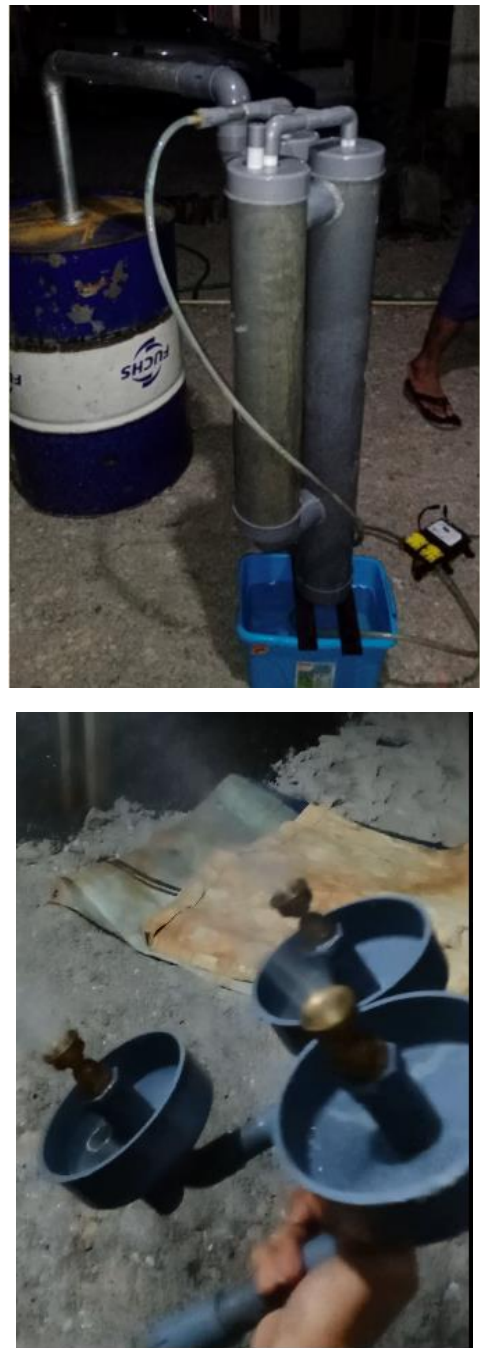

Gambar 4. Filter asap dan nozel saprai berikut adalah kegiatan akhir yaitu foto bersama dengan peserta pengabdian kepada masyarak

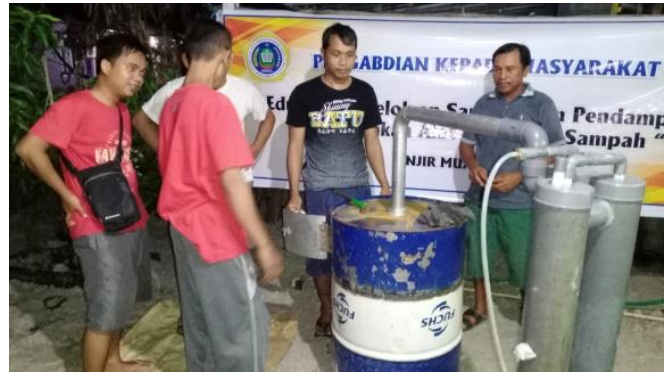

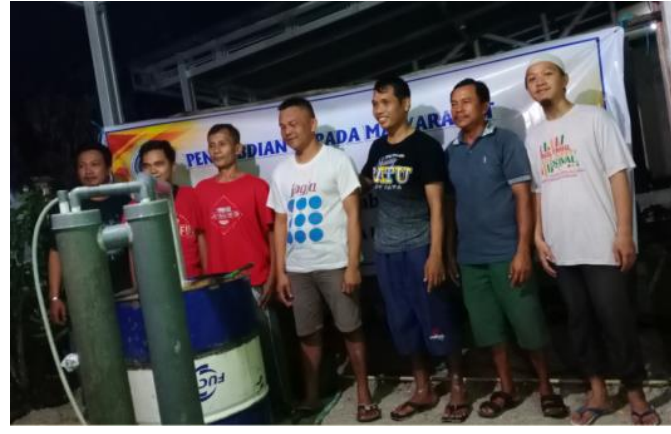

Gambar 5 Dokumentasi kegiatan

\section{KESIMPULAN}

Alat Pembakar Sampah metode saprai ini merupakan alat pembakar sampah yang paling sederhana. Alat ini bertujuan untuk meminimalisasi dampak pembakaran sampah terhadap lingkungan. Pengenalan alat pembakar sampah kepada mitra untuk membantu penangangan sampah. Diharapkan teknologi ini dapat diadaptasi oleh desa lainnya

\section{DAFTAR PUSTAKA}

W. Wardi, 2011, Pengelolaan Sampah Berbasis Sosial Budaya Upaya Mengatasi Masalah Lingkungan di Bali, Jurnal Bumi Lestari, Vol 11 (1).

Riswan , etc, 2011, Pengelolaan Sampah Rumah Tangga di Kecamatan Daha Selatan, Jurnal Ilmu Lingkungan Vol 9 (1).

Rendi, dkk, 2020, Meningkatkan Keterampilan Guru Smk Menggunakan Aplikasi Cad Di Smk Isam Sabilal Muhtadin, Alikhlas Volume 6 No 1. Pp 31-36 
S.A. Yudistirani, L. Syaufina, S. Mulatsih, 2015, Desain Sistem Pengelolaan Sampah Melalui Pemilahan Sampah Organik dan Anorganik Berdasarkan Persepsi Ibu-Ibu Rumah Tangga, Jurnal .Konversi, Vol 4 (2).

Undang-Undang No. 18 Tahun 2008

Arinih, Cici. 2019. Efisiensi Pembakaran Sampah Organik Dan Analisis Kualitas Limbah Yang Dihasilkan Alat Pembakar Sampah Tanpa Asap. Jurnal Teknik Lingkungan, Vol. 01, No. 01, Desember 2019

Eko Naryono dan Soemarno, 2013. Perancangan Sistem Pemilahan,
Pengeringan dan Pembakaran Sampah Organik Rumah Tangga. Indonesian Green Technology Journal.Vol. 2 No. 1, 2013

Permana ,Agus Ganda Dan Muhammad Iqbal. 2020. Mesin Pengolah Sampah Portabel Multiguna Dengan Teknik Termocontrol Dan Termocople. Sebatik 2621069x

Ilhamiyah , Gusti Khairun Ni'mah , Ana Zuraida, Dan Neni Widaningsih. 2020. Sosialisasi Dan Pemanfaatan Tanaman Refugia Sebagai Alternatif Pengendali Hama Tanaman. Jurnal Pengabdian Al-Ikhlas Volume 6 Nomor 1, Agustus 2020 